\title{
PENENTUAN NILAI KETIDAKPASTIAN ANALISIS MERKURI (HG) PADA DAUN SINGKONG MENGGUNAKAN METODE SOLID SAMPLING ATOMIC ABSORPTION SPECTROPHOTOMETRY
}

\section{UNCERTAINTY DETERMINATION IN THE ANALYSIS OF MERCURY IN CASSAVA LEAVE USING SOLID SAMPLING ATOMIC ABSORPTION SPECTROPHOTOMETRY}

\author{
Iwan Sumarlan $^{1^{*}}$, Suhufa Alfarisa ${ }^{2}$ \\ ${ }^{1}$ Program Studi Kimia, Fakultas MIPA Universitas Mataram, Jalan Majapahit No 62, Mataram Lombok, 83125, \\ Nusa Tenggara Barat, Indonesia \\ ${ }^{2}$ Program StudiFisikaUniversitas PGRI Palembang. Jln. Ahmad Yani. No. 9. Palembang 30116. Indonesia \\ *Email: i.sumarlan@unram.ac.id
}

Diterima: 11 Juli 2018. Disetujui: 20 September 2018. Dipublikasikan: 30 September 2018

\begin{abstract}
Abstrak. Merkuri (Hg) merupakan logam berat yang berbahaya bagi tubuh apabila keberadaannya melebihi ambang batas. Penentuan $\mathrm{Hg}$ telah banyak dilakukan salah satunya dengan menggunakan instrumen AAS (Atomic Absorption Spectrophotometry). Pada penelitian ini, analisis kandungan $\mathrm{Hg}$ dari daun singkong dilakukan dengan menggunakan SS AAS (Solid Sampling Atomic Absorption Spectrophotometry) di mana sampel dalam bentuk padatan. Preparasi sampel daun singkong dilakukan dengan menggunakan alat freeze dryer, sebuah alat pengering pada suhu rendah. Dari data percobaan diperoleh nilai akurasi sebesar $98,65 \%$ dan presisi sebesar 98,34\%, batas deteksi $0,00029 \mathrm{ng} / \mathrm{g}$. Konsentrasi $\mathrm{Hg}$ yang diperoleh di sampel daun singkong sebesar 335,069 ng/g dengan nilai ketidakpastian relatif sebesar 3,7274 ng/g dan nilai ketidakpastian diperluas sebesar 7,4548 ng/g.
\end{abstract}

Kata kunci: SS AAS, Ketidakpastian, Merkuri, Presisi, Akurasi, Batas deteksi.

Abstract. Mercury $(\mathrm{Hg})$ is one of the dangerous toxic metal for the human body. Atomic Absorption Spectrophotometry (AAS) may apply for $\mathrm{Hg}$ sample detection. In this research, $\mathrm{Hg}$ in cassava leaf was analyzed using Solid Sampling Atomic Absorption Spectrophotometry (SS AAS) in which the sample was in the solid form. The preparation of sample was done using Freeze Dryer to dry sample in the low temperature. The experimental result showed that the SS AAS method has accuracy of $98.65 \%$ with the precision of $98.34 \%$ and the limit of detection of $0.00029 \mathrm{ng} / \mathrm{g}$. Hg concentration in the sample was also found to be $335.069 \mathrm{ng} / \mathrm{g}$ with its relative uncertainty and wide uncertainty is $3.7274 \mathrm{ng} / \mathrm{g}$ and $7.4548 \mathrm{ng} / \mathrm{g}$ respectively.

Key words: SS AAS, Uncertainty, Mercury, Precision, Accuracy, Limit of Detection

\section{PENDAHULUAN}

Merkuri (Hg) merupakan logam berat berbahaya dan bersifat toksik bagi tubuh. Logam ini dapat terakumulasi di dalam tanaman baik di bagian daun, akar maupun batang. Penentuan kadar merkuri pada sampel tanaman relatif sulit dilakukan karena sifatnya yang sangat sensitif terhadap suhu [1-3]. Salah satu alat yang dapat digunakan untuk mendeteksi $\mathrm{Hg}$ dalam bentuk serbuk adalah SS-AAS. Untuk analisis secara langsung dapat digunakan dan memberikan banyak kemudahan, dibanding menggunakan bahan cair. Bahan padatan tidak memerlukan pelarut ataupun pengenceran melainkan melalui penimbangan dan langsung dilakukan pembakaran dalam tungku grafit [4]. Prinsip kerja alat ini mirip dengan AAS, yaitu logam yang terkandung didalam sampel diubah menjadi atom bebas. Atom bebas tersebut mengabsorpsi radisi dari sumber cahaya yang kemudian diukur pada panjang gelombang tertentu menurut jenis logam dari cuplikan yang dianalisis [5].

Untuk memperoleh data yang akurat perlu ditentukan estimasi ketidakpastiannya. Pada alat SSAAS ini, penentuan ketidakpastian relatif lebih sederhana karena cuplikan yang telah dipreparasi langsung ditimbang dengan alat timbangan yang terhubung dengan alat SS-AAS. Estimasi ketidakpastian pengukuran termuat pada dalam pedoman ISO 17025. Untuk itu laboratorium pengujian harus juga mempunyai dan menerapkan prosedur untuk mengestimasi ketidakpastian pengukuran tersebut. Dalam hal-hal tertentu sifat dasar metode pengujian dapat menghambat penghitungan ketidakpastian pengukuran yang teliti secara metrologis dan absah secara statistik [6-7].

Tanaman pangan sangat mungkin mengandung logam berat seperti merkuri [8-11]. Hal ini tentu akan sangat berdampak buruk bagi kesahatan manusia. Pada penelitian ini akan dilakukan estimasi ketidakpastian hasil pengujian 
unsur $\mathrm{Hg}$ pada daun singkong yang diperoleh di daerah Kaliadem Yogyakarta pada tahun 2007 pasca erupsi merapi.

\section{METODE PENELITIAN}

Bahan: Nitrogen cair, Daun Singkong, Silika Gel, SRM (CRM, certified reference material)

Alat: Freeze Drying Lyovac GT 2, Trivac vacuum pump, Bell jar, gelasakrilik pada "Drying Chamber", Penumbuk Stainless Steel, Mortar Agat, Ayakan 100 mesh, seperangkat alat SS - AAS (AAS 5 EA, ZEISS, PC komputerdengan System Operasi (SO) /22.1 dan AAS 5 EA Control Soft Ware), Lampu Katoda RonggaHg, Tungku Grafit, Timbangan Mikro, Homogeniser Spex

\section{HASIL DAN PEMBAHASAN}

Kurva kalibrasi dibuat untuk mengetahui hubungan antara absorbansi dengan sampel merkuri. Dari data

Table 2 Perhitungan regresi linier untuk memeperoleh persamaan linier guna menghitung kadar Hg dalam daun singkong. kurva kalibrasi akan diperoleh nilai regresi linier (r). kurva kalibrasi dibuat menggunakan reference material NIST 1515 apple leave yang telah disertfikasi oleh Bureue of Analytical Standar. Kurva kalibrasi SRM 1515 ditunjukkan pada table 1. Dari table 1 diperoleh persamaan regesi liniernya seperti pada Tabel 2.

Table 1: Kurva kalibrasi SRM 1515

\begin{tabular}{llll}
\hline Nama & $\begin{array}{l}\text { Massa } \\
\text { SRM }\end{array}$ & Massa Hg & Absorbansi \\
\hline Blanko & 0,0000 & 0,0000 & 0,001 \\
Standar 1 & 0,2790 & 0,0122 & 0,547 \\
Standar 2 & 0,3400 & 0,0149 & 0,662 \\
Standar 3 & 0,5420 & 0,0238 & 0,910 \\
Standar 4 & 0,6740 & 0,0296 & 1,211 \\
\hline
\end{tabular}

\begin{tabular}{llllllll}
\hline No & $\mathrm{Xi}$ & $\mathrm{Yi}$ & $\mathrm{Xi}-\mathrm{Xr}$ & $(\mathrm{Xi}-\mathrm{Xr})^{2}$ & $\mathrm{Yi}-\mathrm{Yr}$ & $(\mathrm{Yi}-\mathrm{Yr})^{2}$ & $(\mathrm{Xi}-\mathrm{Xr})(\mathrm{Yi}-\mathrm{Yr})$ \\
\hline 1 & 0,0000 & 0,001 & $-0,0161$ & $0,259 \times 10^{-3}$ & $-0,666$ & 0,443500 & 0,010722 \\
2 & 0,2790 & 0,547 & $-0,0039$ & $0,152 \times 10^{-3}$ & $-0,12$ & 0,014400 & 0,000468 \\
3 & 0,3400 & 0,662 & 0,0077 & $0,001 \times 10^{-3}$ & $-0,005$ & 0,000025 & 0,000006 \\
4 & 0,5420 & 0,910 & 0,0077 & $0,059 \times 10^{-3}$ & 0,247 & 0,061000 & 0,001902 \\
5 & 0,6740 & 1,211 & 0,0135 & $0,182 \times 10^{-3}$ & 0,544 & 0,295900 & 0,007344 \\
& $\mathrm{Xr}: 0,0161$ & $\mathrm{Yr}: 0,667$ & 0 & $5,174 \times 10^{-3}$ & 0 & 0,8148 & 0,020442 \\
\hline
\end{tabular}

Dari Tabel 2 diperoleh $X$ rerata $=0,0161, \mathrm{Y}$ rerata $=0,667, \mathrm{a}=0,0308$ dan $\mathrm{b}=39,510$ dan $\mathrm{r}=0,9956$ sehingga diperoleh persamaan $\mathrm{Y}=39,510 \mathrm{x}+0,0308$

Tabel 3. Perhitungan untuk batas deteksi dan variansi residual (s)

\begin{tabular}{ccccc}
\hline No & $\mathbf{X i}$ & $\mathbf{Y i}$ & $\mathbf{Y}^{*}$ & $\left(\mathbf{Y i}-\mathbf{Y}^{*} \mathbf{2}\right.$ \\
\hline 1 & 0,0000 & 0,001 & 0,0308 & 0,0009 \\
2 & 0,2790 & 0,547 & 0,5128 & 0,0012 \\
3 & 0,3400 & 0,662 & 0,6194 & 0,0018 \\
4 & 0,5420 & 0,910 & 0,9711 & 0,0033 \\
5 & 0,6740 & 1,211 & 1,2002 & 0,0001 \\
Jumlah & $\mathbf{0 , 0 8 0 5}$ & $\mathbf{2 , 5 9 3}$ & & $\mathbf{0 , 0 0 7 3}$ \\
\hline
\end{tabular}

Nilai $Y^{*}$ diperoleh melalui persamaan $\mathrm{Y}=39,510 \mathrm{x}+0,0308$

$\mathrm{Sy} / \mathrm{x}=\mathrm{Sd}=\sqrt{\sum(Y-Y *) 2} / n-2$

$\mathrm{Sy} / \mathrm{x}=\mathrm{Sd}=\sqrt{0,0073 / 3}$

$\mathrm{Sy} / \mathrm{x}=\mathrm{Sd}=0,0493$

$\mathrm{S}($ variansi Residual $)=0,0073 / 2=0,0024$

Batas deteksi $=0,00029 \mathrm{ng}$ 
Tabel 4. Kadar hasil analisis Hg dalam SRM

\begin{tabular}{cccc}
\hline No & $\begin{array}{c}\text { Konsentrasi Hg pada SRM } \\
\text { NIST 1515 (Xs) }\end{array}$ & $\begin{array}{c}\text { Konsentrasi (ng/g) Hg yang } \\
\text { terdeteksi (Xi) }\end{array}$ & $\mathbf{( X i - X r ) ~}^{\mathbf{2}}$ \\
\hline 1 & 0,0440 & 0,0416 & 0,0000090 \\
2 & 0,0440 & 0,0438 & 0,0000006 \\
3 & 0,0440 & 0,0446 & 0 \\
4 & 0,0440 & 0,0461 & 0,0000002 \\
5 & 0,0440 & 0,0471 & 0,0000063 \\
6 & 0,0440 & 0,0427 & 0,0000036 \\
7 & 0,0440 & 0,0452 & 0,0000004 \\
8 & 0,0440 & 0,0456 & 0,0000010 \\
9 & 0,0440 & 0,0431 & 0,0000023 \\
10 & 0,0440 & 0,0468 & 0,0000049 \\
& $\mathbf{X s}=\mathbf{0 , 0 4 4 0}$ & $\mathbf{X r = 0 , 0 4 4 6}$ & $\mathbf{\Sigma} \mathbf{4 9} \mathbf{x} \mathbf{~ 1 0}^{-\mathbf{6}}$ \\
\hline
\end{tabular}

Table 5: kadar Hg pada daun singkong

\begin{tabular}{cc}
\hline No & Kadar Hg (ng/n) \\
\hline 1 & 333,84 \\
2 & 348,58 \\
3 & 347,00 \\
4 & 351,61 \\
5 & 324,97 \\
6 & 321,60 \\
7 & 338,52 \\
8 & 321,18 \\
9 & 339,95 \\
10 & 323,44 \\
Rerata & $\mathbf{3 3 5 , 0 6 9 \pm 1 1 , 7 7 2}$ \\
\hline
\end{tabular}

Dari Tabel 4 diperoleh nilai hasil rerata $(\mathrm{Xr})$ analisis sebesar $0,0446 \mu \mathrm{g} / \mathrm{g}=44,6 \mathrm{ng} / \mathrm{g}$ dan standar deviasi 0,000074 sehingga kadar hasil analisis $\mathrm{Hg}$ pada SRM menjadi 44,6 $\pm 0,000074 \mathrm{ng} / \mathrm{g}$. Dari table 4 di atas juga diperoleh nilai akurasi: $98,65 \%$ dan presisi: $98,34 \%$. Nilai akurasi dan presisi diperoleh melalui rumus:

Akurasi $=\left(100-\frac{k s-h a}{h a}\right) \times 100 \%$

$$
\mu r=\sqrt{\mu p n b(I)^{2}+\mu p n b(I I)^{2}+(\mu s / c s)^{2}+(\mu p / c s p)^{2}+(\mu c u p / c c u p)^{2}+(\mu k k l)^{2}}
$$

di mana: $\mu \mathrm{s}=$ Ketidakpastian baku standar SRM; $\mu \mathrm{p}$ $=$ Ketidakpastian baku percobaan standarSRM; $\mu$ cup $=$ ketidakpastian baku cuplikan; $\mu \mathrm{kkal}=$ ketidakpastian kurva kalibrasi; $\mu$ pnb $=$ ketidakpastian

Ketidakpastian pengukuran $\mathrm{Hg}$ pada sampel daun singkong meliputi:

1. Ketidakpastian baku penimbangan I SRM (dari sertifikat menunjukkan ketidakpastian total neraca adalah $0,0143 \mathrm{mg}$ (sudah dikalikan 2):
Di mana: $k s$ kadar Hg dalam SRM dan ha kadar Hg hasil analisis

Presisi $=\left(100-\frac{s d}{h a}\right) \times 100 \%$

Penentuan nilai ketidakpastian hasil analisis $\mathrm{Hg}$ dalam sampel daun singkong menggunakan persamaan di bawah ini. baku penimbangan; csp $=$ konsentrasi standar percobaan; $\operatorname{ccup}=$ konsentrasi cuplikan; $\mathrm{cs}=$ konsentrasi Hg dalam SRM

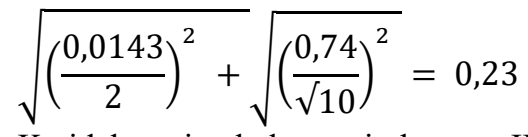

2. Ketidakpastian baku penimbangan II sampel daun ketela (dari sertifikat menunjukkan ketidakpastian total neraca adalah 0,0143 mg $($ sudah dikalikan 2$)=$ 


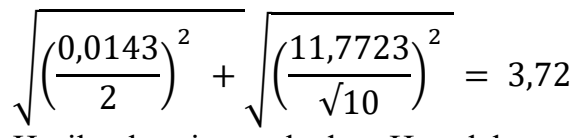

3. Hasil ekperimen kadar $\mathrm{Hg}$ dalam daun singkong $335,069 \pm 11,7723 \mathrm{ng} / \mathrm{g}$ maka ketidakpastian instrument, $\mu=11,7723 / \sqrt{ } 10$ $=3,72 \mathrm{ng} / \mathrm{g}$

4. Datta sertifikat NIST 1515 menunjukkan kadar Hg 0,0440 $\pm 0,0039 \mu \mathrm{g} / \mathrm{g}$ maka harga baku kemurnian standar $\mu=0,0039 / 2=1,95$ $\mathrm{ng} / \mathrm{g}$.

$$
\begin{gathered}
\mu r=\sqrt{(0,23)^{2}+(3,72)^{2}+(1,95 / 44)^{2}+(0,23 / 44,6)^{2}+(3,72 / 335,069)^{2}+(0,02)^{2}} \\
\mu r=3,7274 \\
\mu d=2 x \mu r=7,4548
\end{gathered}
$$

\section{KESIMPULAN}

Dari data percobaan diperoleh nilai akurasi sebesar $98,65 \%$ dan presisi sebesar $98,34 \%$, batas deteksi $0,00029 \mathrm{ng} / \mathrm{g}$. Konsentrasi $\mathrm{Hg}$ yang diperoleh di sampel daun singkong sebesar335,069 ng/g dengan nilai ketidakpastian relatif sebesar $3,7274 \mathrm{ng} / \mathrm{g}$ dan nilai ketidakpastian diperluas sebesar 7,4548 ng/g.

\section{DAFTAR PUSTAKA}

[1] Palar, 1998, Pencemaran dan Toksikologi Logam Berat, RinelaCipta Bandung

[2] Sukib, S., \& Mutiah, M. (2016). Eliminasi Gangguan Matriks Dalam Analisis Merkuri $\mathrm{Hg}$ Sebagai Senyawa Kompleks Thio Michler's Keton Secara Spektrofotometri. Jurnal Pijar Mipa, 11(1).

[3] Sheila, 1994, Source and Forms of Potentially Toxic metal in Soil-plan System, Chichester

[4] SamindanWisjahudin, 2007, Estimasi Ketidakpastian Analsis $\mathrm{Hg}$ dalam Cuplikan Ikan dan Udang dengan metode SSAAS, Prosiding PPI-PDIPTDN Pusat Akselerator dan proses Bahan-BATAN

[5] Wen-Yi Chen, Yu-Chun Wang dan Mao-sung Luo, 2002, Determination of Total Mercury and Methyl Mercury in Human Hair by Using Graphite-Furnace Atomic Absorption Spectrophotometry Using 2,3Dimercaptopropane-1-sulfonate as a Complexing Agent, The Japan Society for Analytical Chemistry.

[6] Zulfikah, Z., Basir, M., \& Isrun, B. (2014). Konsentrasi merkuri $(\mathrm{Hg})$ dalam tanah dan jaringan tanaman kangkung (Ipomoea Reptans) yang diberi bokashi kirinyu (Chromolaena Odorata L.) pada limbah tailing
5. Tidakpastian baku presisi metode $0,0446 \pm$ $0,00074 \mu \mathrm{g} / \mathrm{g}$ maka ketidakpastian $\mu=$ $0,00074 / \sqrt{ } 10=0,23 \mathrm{ng} / \mathrm{g}$

6. Ketidakpastian baku kurva kalibrasi var $(X)=S^{2} / b^{2}$ dimana $S^{2}=0,0024, b=39,510$. $\operatorname{Var}(\mathrm{x})=\mathrm{s}^{2} / \mathrm{b}^{2}=(0,0024)^{2} /(39,510)^{2}=2$, $6833 \times 10^{-4}$ maka ketidakpastian kurva kalibrasi $\mu(\mathrm{x}, \mathrm{y})=\sqrt{ } \mathrm{var}=\sqrt{2}, 6833 \times 10^{-4}=$ 0,02 